INOX: Implantes

\title{
Electrochemical behavior of two austenitic stainless steel biomaterials
}

\author{
Comportamento eletroquímico de dois aços inoxidáveis austeníticos \\ utilizados como biomateriais
}

\section{Enrico J. Giordano \\ CCDM - Universidade Federal de São Carlos \\ E-mail: enrico@ccdm.ufscar.br}

\section{Neusa Alonso-Falleiros \\ EPUSP - Departamento de Engenharia Metalúrgica e Materiais E-mail:neusa.alonso@poli.usp.br}

\section{Itamar Ferreira}

FEM/UNICAMP - Departamento de Engenharia de Materiais E-mail: itamar@fem.unicamp.br

\section{Oscar Balancin \\ UFSCar - Departamento de Engenharia de Materiais E-mail:balancin@ufscar.br}

\begin{abstract}
Resumo
O presente trabalho avaliou a resistência à corrosão localizada de dois aços inoxidáveis austeníticos utilizados na fabricação de implantes ortopédicos: o aço ASTM F138, material metálico atualmente mais utilizado em aplicações ortopédicas e o aço ISO 5832-9, aço com adição de nióbio e nitrogênio e que vem sendo apontado como uma alternativa para a substituição do aço F138, para aplicações mais severas de carregamento e tempo de permanência no interior do corpo humano. Ensaios de polarização mostraram que o aço ISO 5832-9 apresenta resistência à corrosão localizada muito superior à do aço F138. O potencial crítico de pite do aço ISO 5832-9 não foi observado na curva de polarização cíclica até o potencial de transpassivação do material. O ensaio potenciostático de corrosão por risco confirmou a superioridade do aço ISO 5832-9. Observou-se a reconstituição do filme passivo danificado mecanicamente, mesmo em potenciais tão elevados como $800 \mathrm{mV}$ SCE. Análises por microscopia eletrônica de varredura confirmaram a presença de pites de corrosão de crescimento estável, na superfície da amostra de aço F 138, e a ausência desses pites, na amostra do aço ISO 5832-9. A maior resistência à corrosão localizada do aço ISO 5832-9 é, principalmente, atribuída ao aumento da estabilidade do filme passivo, sendo favorecida pela presença do nitrogênio em solução sólida intersticial, na austenita desse aço.
\end{abstract}

Palavras-chave: Biomateriais metálicos, corrosão localizada, aços inoxidáveis austeníticos, Fase Z, ISO 5832-9.

\begin{abstract}
Potentiodynamic and potentiostatic polarization measurements were conducted in $0.9 \% \mathrm{NaCl}$ solution to investigate the localized corrosion susceptibility of two austenitic stainless steel biomaterials: a low nitrogen, according to ASTM F 138 - the metallic material most widely utilized today in orthopedic applications; and a nitrogen- and niobium-bearing stainless steel, according to ISO 5832-9, which has shown a promising potential as a substitute of the F 138 steel for more severe loading applications and longer times inside the human body. The polarization tests revealed that the ISO 5832-9 steel is more corrosion resistant than the F 138. The critical pitting potential of the ISO 5832-9 steel could not be observed in the cyclic polarization curve up to the value of potential corresponding to its transpassivity. The potentiostatic scratch test confirmed the superiority of the ISO 5832-9 steel, which heal the mechanically damaged passive film at applied potential as high as $800 \mathrm{mV}$ (SCE). Scanning electron microscopy (SEM) examination confirmed the presence of corrosion pits - lacelike pits - in a stable growth stage on the surface of F 138 steel and the absence of such pits in the specimens of the ISO 5832-9
\end{abstract}


steel. The higher corrosion resistance of the latter is attributed to the increased stability of the passive film and the high tendency to repassivate, which, in turn, is favored by the presence of nitrogen in interstitial solid solution in the austenite of this type of steel.

Keywords: Austenitic stainless steel, localized corrosion, Z-phase, ISO 58329, metallic biomaterials, orthopedic implant.

\section{Introduction}

The deterioration of metallic implants in the human body is undesirable for two main reasons: the degradation process may impair the structural integrity of the implant and the products released through the degradation process may culminate in adverse biological reactions in the implanted patient. This deterioration may result, for instance, from the corrosion of the implanted metal. Corrosion of the implant surface may be uniform (general corrosion) or localized, affecting specific regions where the bodily fluids remain stagnated (crevice corrosion) or on localized random sites on the metal surface (pitting corrosion). Moreover, the combination of the electrochemical corrosion process and of cyclic mechanical loads can, through the synergy corrosion-fatigue, accelerate the release of metallic particles (debris) and ions, leading to premature structural failure of the implant.

It is known that austenitic stainless steels owe their corrosion resistance to the formation of a superficial protective oxide film rich in $\mathrm{Cr}$, named passive film, which, by adhering to the metal surface, acts as a kinetic barrier, inhibiting the corrosion process and keeping the release of ions at very low levels. Despite the high generalized corrosion resistance of this type of steel, they are susceptible to localized pitting or crevice corrosion.

For over ten years, the corrosion resistance of high nitrogen stainless steels has been the favorite topic of corrosion studies seeking to elucidate the role of nitrogen in the various processes: anodic dissolution; passivation; pitting corrosion; crevice corrosion and corrosion associated with mechanical loads (Sivakumar, Kamachi Mudali, Rajeswari, 1994; Levey and Van Bennekom, 1995; Rondelli, Vicentini, Cigada, 1995; Azuma, Miyuki, Kudo, 1996; Grabke, 1996; JargeliusPettersson, 1996; Kamachi Mudali et al., 1996; Rondelli, Vicentini, Cigada, 1997; Jargelius-Pettersson, 1999). Small amounts of nitrogen suffice to promote significant variations in the mechanical and corrosion properties of the steels. The ISO 5832-9 steel, a nitrogen- and niobium-bearing austenitic stainless steel, has been indicated as an alternative to substitute F 138 steel, the metallic material most widely employed in orthopedics, for more severe loading applications and longer periods inside the human body, due to the combination of high strength, even in the annealed condition, associated with high localized corrosion resistance. Although advantageous, the influence of some features of the ISO 5832-9 such as the presence of Z-phase - inherent phase in this type of austenitic stainless steel (Giordani et al., 2004) - on the corrosion resistance is not well understood.

This article reports on an evaluation, based on potentiodynamic and potentiostatic polarization tests, of the localized corrosion resistance, in an aqueous $0.9 \% \mathrm{NaCl}$ solution, of two austenitic stainless steels used as biomaterials - F 138 and ISO 5832-9. The effect of nitrogen on electrochemical behavior is also discussed, as are features of the corrosive attack investigated by SEM.

\section{Materials and methods}

The materials studied were the austenitic stainless steels ASTM F 13897 and ISO 5832-9 (ASTM 1586), received as rolling bars with a $15.87 \mathrm{~mm}$ diameter (5/8"). Table 1 lists the chemical compositions of the steels.

All electrochemical tests were performed at least in triplicate in a $0.9 \%$ $\mathrm{NaCl}$ in de-ionized and distillated water solution at $22 \pm 1^{\circ} \mathrm{C}$ for the two steels annealed at $1030^{\circ} \mathrm{C}$ for 1 hour. Before being embedded in polyester resin, the specimens were subjected to a surface passivation treatment in an aqueous solution of $20 \% \mathrm{HNO}_{3}$ at $35^{\circ} \mathrm{C}$ for 60 minutes, to prevent crevice corrosion at the metal/resin interface. The exposed transversal area, polished down to $1 \mu \mathrm{m}$ with diamond paste, was approximately $1 \mathrm{~cm}^{2}$. The potential was applied and the corrosion current recorded using a potentiostat (EG\&G Princeton Applied Research, model 273A) coupled to a microcomputer. The reference electrode used was a saturated calomel electrode (SCE) and the counter electrode was of platinum. The specimens were immersed in the electrolyte one hour before the tests to reach a steady state potential.

The cyclic potentiodynamic polarization tests were conducted with a potential scan rate of $0.33 \mathrm{mV} / \mathrm{s}$ $(1200 \mathrm{mV} / \mathrm{h})$. The initial potential was $-750 \mathrm{mV}$ (SCE) and the potential sweep was reversed when the anodic current density reached $100 \mu \mathrm{A} / \mathrm{cm}^{2}$. The cyclic polarization curves are presented following the conventions of the ASTM G3 standard and the terminology of the ASTM G15 standard.

The potentiostatic scratch test, initially proposed by Pessal and

Table 1 - Chemical compositions of the steels studied (wt \%).

\begin{tabular}{c|c|c|c|c|c|c|c|c}
\hline Material & $\mathbf{C}$ & $\mathbf{M n}$ & $\mathbf{N i}$ & $\mathbf{C r}$ & $\mathbf{M o}$ & $\mathbf{N}$ & $\mathbf{N b}$ & $\mathbf{F e}$ \\
\hline F 138 & 0.01 & 1.7 & 14.1 & 17.4 & 2.1 & 0.04 & - & bal. \\
\hline ISO 5832-9 & 0.02 & 3.6 & 10.6 & 21.1 & 2.4 & 0.37 & 0.42 & bal. \\
\hline
\end{tabular}


Liu (1971), is an alternative way to determine the critical pitting potential $\left(E_{c}\right)$ of passivable metals. In this method the passive film is slightly damaged, here using an alumina tip, while the potential is applied by using the potentiostat which also records the corrosion current density developed before, during, and after scratching. The starting potential must be located in the passive region. If the damaged areas repassivate after the scratch, the current density drops to values near zero. Then, scratching is repeated at higher potential values (here using $20 \mathrm{mV}$ steps) up to a potential value at which the damaged passive film does not repassivate, and the current density remains at high values or even increases with time. In this way, $\mathrm{E}_{\mathrm{c}}$ is defined as the more noble value of potential above which the damaged film does not heal.

After testing, examinations on the exposed surface of the specimens were conducted in a scanning electron microscope (Jeol, model JSM-5900LV) to check the features of the corrosive attacks on the steels.

\section{Results and discussion}

Figure 1 shows representative cyclic potentiodynamic polarization curves of the F 138 and ISO 58329 steels. Table 2 lists the values of the parameters obtained from these tests. The electrochemical behavior displayed by F 138 steel was typical of materials presenting a well-defined critical pitting potential. This parameter defines the maximum potential above which breakdown of the material's passivity occurs through nucleation and the stable growth of one or more corrosion pits. This is characterized by a marked and irreversible increase of the corrosion current density until it reaches the reversal current, where the potential sweep is reversed. Another feature of the F 138 steel's polarization curve that characterizes the occurrence of pitting corrosion is the development of a hysteresis during the reversed scan
(Rondelli, Vicentini, Cigada, 1997). The region of hysteresis is characterized by the growth of pits nucleated at the critical pitting potential which are unable to repassivate immediately after the reversal in the scan direction, even at potential values lower than $\mathrm{E}_{\mathrm{c}}$. When the current density becomes equal to the passive current and the hysteresis closes, the protection potential $\left(E_{p}\right)$ is defined, below which the existing pits are repassivated (Cahoon, Bandyopadhya, Tennese, 1975).

The ISO 5832-9 steel displayed an electrochemical behavior rather different. The critical pitting potential for this material was not reached up to the value of potential corresponding to its transpassivity, unlike determined by Pan and coworkers (2000), who indicated a value of $E_{c}$ of $1100 \mathrm{mV}$ (SCE) for a high-N steel (according

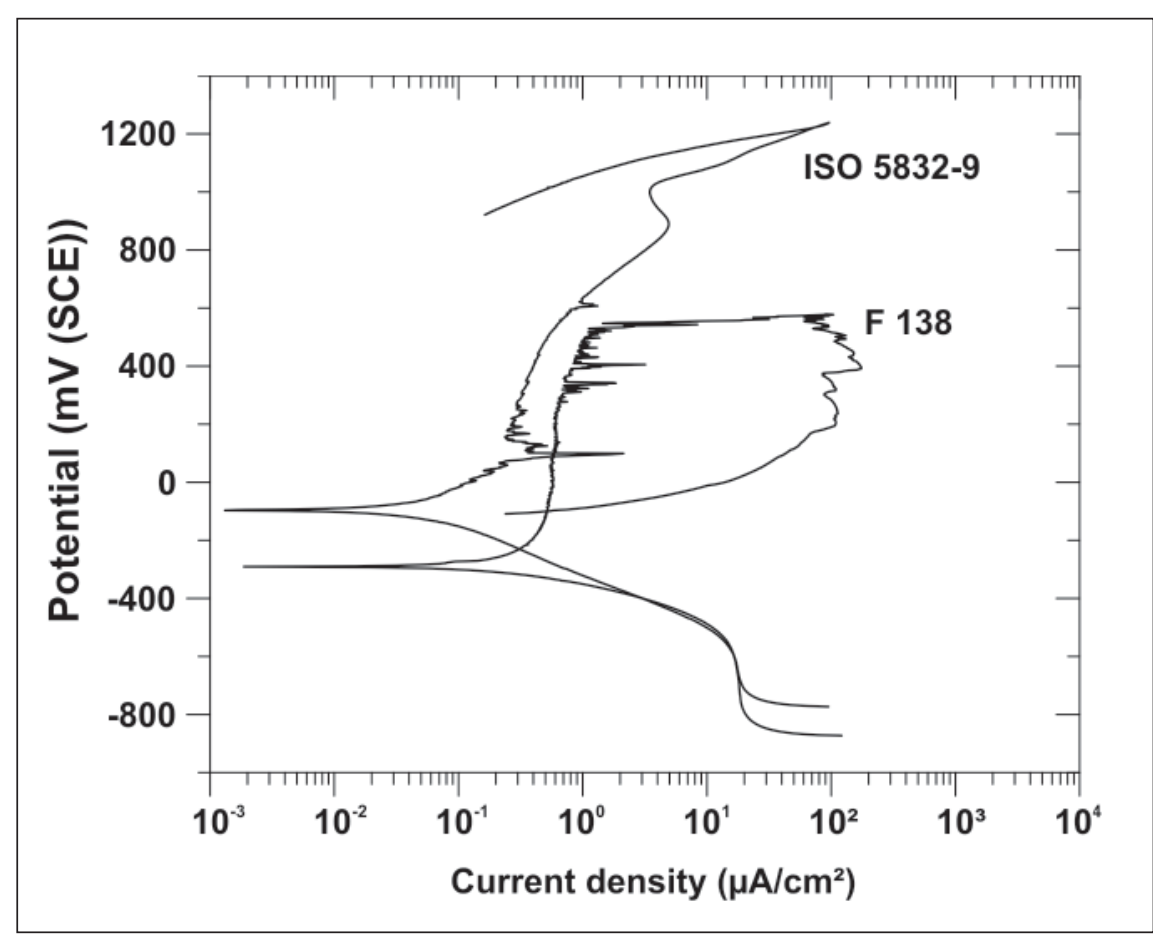

Figure 1 - Cyclic potentiodynamic polarization curves in $0.9 \% \mathrm{NaCl}$ solution.

Table 2 - Results from the cyclic potentiodynamic polarization test.

\begin{tabular}{c|c|c}
\hline Material & $\mathrm{E}_{\mathrm{c}}(\mathrm{mV}(\mathrm{SCE}))$ & $\mathrm{E}_{\mathrm{p}}(\mathrm{mV}(\mathrm{SCE}))$ \\
\hline F 138 & $568 \pm 15$ & $-2 \pm 146$ \\
\hline ISO 5832-9 & $>1000$ & - \\
\hline
\end{tabular}


1996; Jargelius-Pettersson, 1996; Rondelli, Vicentini, Cigada, 1997; Jargelius-Pettersson, 1999; Truman, Coleman, Pirt, 1977; Pickering, 1989; Lim et al., 2001), although the steel has a rather higher concentration of chromium and molybdenum.

$2 \mathrm{H}_{2} \mathrm{O} \rightarrow \mathrm{O}_{2}+4 \mathrm{H}^{+}+4 \mathrm{e}^{-}$

Cahoon and coworkers (1975) argue that the crevice corrosion resistance of the material can be evaluated by the difference between the critical pitting potential and the protection potential $\left(E_{c}-E_{p}\right)$. This difference represents the size of the hysteresis developed during the cyclic polarization test and the tendency of the material to repassivate after pitting. However, one must be cautious in accepting this statement unconditionally. In view of the importance attributed to this parameter, some considerations should be made. According to Rondelli and coworkers (1997), the value of the $E_{p}$ depends on the dimension of the pitting attack and hence on the modifications in the chemical composition of the solution inside the pits ( $\mathrm{pH}$ and concentration of aggressive ions). Thus, the deeper the pit is, the more aggressive the electrolyte inside it will be and the more difficult it will be for this pit to repassivate (Wilde and Williams, 1971). Therefore, if only one pit is nucleated on the surface of the metal at $E_{c}$, it grows stably until it reaches the reversal current and the pit has an interval of time to propagate stably, increasing its size. Sufficiently aggressive conditions are therefore created inside the pit, preventing its repassivating immediately after the potential sweep is reversed. That is the reason for forming the hysteresis down to a sufficiently low potential for repassivation to occur. On the other hand, if various pits are nucleated at $\mathrm{E}_{\mathrm{c}}$, the maximum current density for reversal of the sweep to occur is reached more rapidly. As a result, each of the nucleated pits has a shorter time interval to grow stably and deepen and, consequently, the conditions inside each pit are less aggressive, facilitating its repassivation at higher potentials.
This consideration is based on a study developed by Bandy and Cahoon (1977), which suggests that $\mathrm{E}_{\mathrm{p}}$ is not an intrinsic property of the material, since its value varies with the amount of localized attack induced by polarization. This discussion may explain the considerable scattering in the values of $E_{p}$ obtained for the F 138 steel, as also observed by Rondelli and coworkers (1997).

A noteworthy feature that can be observed in the polarization curve of the two steels is the presence of a serrated portion in the passive region. This aspect characterizes a passive instability, where a localized breakdown of the passive film (pitting initiation) and its rapid repassivation occur. Grabke (1996) defines an unstable pitting nucleation potential $\left(\mathrm{E}_{\mathrm{r}}\right)$ as the potential above which unstable pits are nucleated on the metal surface. Unstable pits are pits that repassivate and do not grow stably. Based on this assumption, the author argues that nitrogen produces a greater increase in the $E_{c}$ than the in $E_{r}$, suggesting that nitrogen promotes repassivation of pits, causing a broadening of the interval between $E_{c}$ and $E_{r}$, as was also observed in this study (Figure 1). So the beneficial effect of nitrogen is attributed primarily to the kinetics of repassivation and not of pitting initiation. Grabke (1996) also suggests that immediately after the localized breakdown of the passive film, the repulsive interaction between the negatively charged nitrogen $\left(\mathrm{N}^{\delta-}\right)$, already segregated at the metal/oxide interface or further enriched by anodic segregation, and the aggressive $\mathrm{Cl}^{-}$ions undoubtedly will lead to the desorption of the $\mathrm{Cl}^{-}$ions, since segregated nitrogen cannot rapidly move away. Thus, the repulsion of the aggressive ions may be responsible for the rapid repassivation of nucleated pits in a broad interval of potentials, in steels containing a fairly high concentration of nitrogen in solution. According to the same author, rapid repassivation may be favored by the effect of nitrogen in buffering $\mathrm{pH}$ by the ammonium ions formation, according to reaction (2). In addition, some authors suggest the formation of corrosion resistant $\mathrm{Cr}$ - or Mo-nitrides in the pit bottom, suppressing the growth of the pit (Levey and Van Bennekom, 1995; Jargelius-Pettersson, 1996; Lu, Ives, Clayton, 1993).

$\mathrm{N}^{3-}+4 \mathrm{H}^{+} \rightarrow \mathrm{NH}_{4}^{+}$

An interesting aspect of the electrochemical behavior of ISO 58329 steel was observed when the potential scan was reversed. In this region, it was expected that the forward and reverse potential scans would be identical, which was not the case. This behavior was expected because the breakdown of the passive film was not reached, so no stable pits, which would have led to the formation of hysteresis, developed on the metal surface. Two explanations can be proposed for this behavior. During the corrosion process in the passive or even transpassive region, the material may develop a more effective kinetic barrier against corrosion processes, for example, by the negatively charged $\mathrm{N}^{\delta-}$ enrichment beneath the passive film or even by the thickening of the passive layer with increasingly applied potential (Grabke,1996). Thus, when the potential scan is reversed, the kinetic barrier is greater because it was developed at nobler potentials. Having stated this, it is coherent to expect that the corrosion current density developed during the reverse scan is lower than that developed during the forward scan. A second alternative to explain the displacement of the reverse scan curve to lower current density values is attributed to the development of $\mathrm{O}_{2}$ microbubbles formed at potentials above the oxygen evolution potential, according to reaction (1). These $\mathrm{O}_{2}$ microbubbles, trapped at the metal surface, reduce the metal/solution contact area. Hence, the displacement of the reverse scan curve occurs through the reduction of the area of metal exposed to corrosion.

Another interesting behavior that stands out for its relevance is the difference in passive current density developed by the two materials. Figure 1 clearly shows that the current density developed by the ISO 5832-9 steel in the 
passive region is considerably lower than that of the F 138 steel. Passive current density is an indicative of the stability of the passive film (Levey and Van Bennekom, 1995). The lower the passive current, the more effective is the passive film as a kinetic barrier against corrosion reactions, and the lower will be the corrosion rate of the metal in the passive condition. The higher concentration of molybdenum or even the synergistic effect of nitrogen and molybdenum (Levey and Van Bennekom, 1995; Jargelius-Pettersson, 1999; Bandy and Cahoon, 1977; Lu, Ives, Clayton, 1993 ) through the co-segregation and the formation of a surface array which suppresses dissolution could be responsible for a passive film that is more efficient as a kinetic barrier in the ISO 5832-9 steel. The reduction in the passive current density can be attributed to the mechanism of nitrogen negativelycharged enrichment beneath the passive film. Nitrogen present in this form suppresses the adsorption of aggressive $\mathrm{Cl}^{-}$ions, helping to maintain the stability and integrity of the passive film and ensuring its efficiency as a kinetic barrier against corrosive processes.

In metallic biomaterials, whose functionalities are performed inside the human body in contact with bodily fluids, the reduction in passive current density is especially relevant. A decrease in the corrosion rate inside the human body will obviously reduce the release of metallic ions into the adjacent tissues or even into the bloodstream. This release of metallic ions, chiefly chromium and nickel, is usually responsible for a large part of the adverse reactions involved in metallic implants, and may often lead to the need for their replacement (Sivakumar, Kamachi Mudali, Rajeswari, 1994; Rondelli, Vicentini, Cigada, 1997; Cahoon, Bandyopadhya, Tennese, 1975).

In addition to the toxic effect associated with the release of metallic ions, it is known that the accumulation of these cations inside a crevice, i.e., an occluded cell with stagnated electrolyte, causes the concentration of aggressive ions (e.g., $\mathrm{Cl}^{-}$) to increase through electrostatic attraction. The hydrolysis of metallic salts, for example according to reaction (3), also reduces the $\mathrm{pH}$ inside the crevice. The combination of a high concentration of $\mathrm{Cl}^{-}$and high acidity severely increases the aggressiveness of the environment and stimulates the dissolution of more metallic ions inside the crevice, rendering the process self-catalytic. Therefore, the lower passive current density of ISO 5832-9 steel in comparison with that of F 138 steel suggests that crevice corrosion can be minimized by reducing the aggressiveness inside crevices, which are common in multi-component orthopedic implants. One of the most common examples of crevice is the regions that are established between the holes in a straight plate for osteosynthesis and the heads of cortical screws. Thus, there is an evident need to keep the release of ions in metallic biomaterials as low as possible.

$$
\mathrm{M}^{+} \mathrm{Cl}^{-}+\mathrm{H}_{2} \mathrm{O} \rightarrow \mathrm{MOH}+\mathrm{H}^{+} \mathrm{Cl}
$$

In view of the above described observations, it was possible to verify the superiority of the ISO 5832-9 steel in terms of localized corrosion resistance when compared to the F 138 steel. The influence of nitrogen on corrosion resistance appears to be closely connected with the stability of the passive layer. This finding is confirmed by the increase in the $\mathrm{E}_{\mathrm{c}}$ value and by the reduction in the passive current density.

The potentiostatic scratch test confirmed the superiority of the ISO 5832-9 steel when compared to the F 138, and also confirmed the high ability of the ISO 5832-9 steel to repassivate. According to the idealizers of this test method (Pessall and Liu, 1971), the potentiostatic scratch test allows the determination of the $\mathrm{E}_{\mathrm{c}}$ value for the stainless steels in aqueous medium from the tendency of the material to repassivate and not from the tendency of the material to maintain its passivity, as in the cyclic polarization test. Thus, the $\mathrm{E}_{\mathrm{c}}$ value, determined by this technique depends only on the metal composition and structure and not on the electrolyte characteristics, eliminating variables such as potential scan rate and specimen surface finish. In this test, after verifying the stability of the passive film for a certain period $(\approx 120 \mathrm{~s})$ in a given potential, where the corrosion current density must be close to zero, the mechanical damage of the passive film (scratch) is done. In this instant, the corrosion density presents a sharp increase. When repassivation occurs after the scratch, the current density must decrease rapidly to values close to zero. The applied potential is still kept during some time to verify the film stability in the repassivated region. Figure 2(a) shows this behavior for the ISO 5832-9 steel for an applied potential of $800 \mathrm{mV}$ (SCE). On the other hand, when repassivation after the scratch does not occur, the current density does not stabilize in values close to zero and increases with time, as shown in Figure 2(b) for the F 138 steel for an applied potential of $400 \mathrm{mV}$ (SCE). Then the $\mathrm{E}_{\mathrm{c}}$ value is defined as the potential above which the repassivation of the damaged surface by the scratch no longer occurs. In this test, the F 138 steel presented an average $\mathrm{E}_{\mathrm{c}}$ value of $427 \pm 34 \mathrm{mV}$ (SCE). The ISO 5832-9 steel, on the other hand, showed a much larger repassivation tendency with an $\mathrm{E}_{\mathrm{c}}$ value above $800 \mathrm{mV}$ (SCE), which was the upper limit for this test.

The increase of the $E_{c}$ value for this test may also be attributed to the nitrogen in solid solution in the ISO 5832-9 steel. Resorting once more to the mechanism proposed by Grabke (1996), immediately after the breakdown of the passive film (mechanically in this case), there is a segregation of nitrogen, negatively charged $\left(\mathrm{N}^{\delta-}\right)$, on the metal surface, by anodic dissolution of the unprotected surface. This segregation promotes the removal of aggressive ions $\left(\mathrm{Cl}^{-}\right)$by the repulsive interaction with the segregate species $\mathrm{N}^{\delta-}$. A sufficiently adequate condition is created so that repassivation occurs, even in potentials as noble as $+800 \mathrm{mV}$ (SCE). 


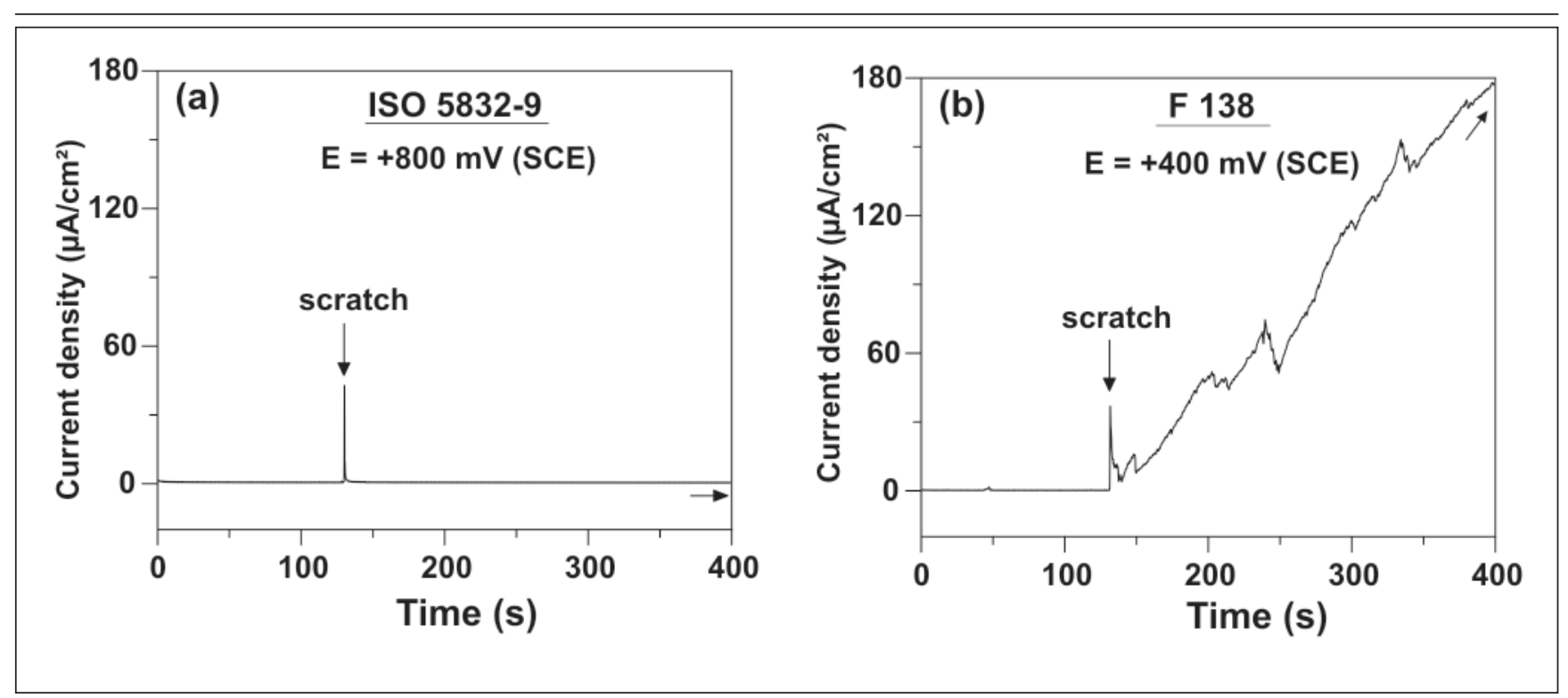

Figure 2 - Electrochemical behavior observed in the potentiostatic scratch test in $0.9 \% \mathrm{NaCl}$ solution (Giordani, Ferreira, Balancin, 2007).

Figures 3 and 4 illustrate the results of the SEM examinations aimed at characterizing the relevant features of corrosive attack on the surfaces of the two steels submitted to the cyclic potentiodynamic polarization test. These examinations revealed the presence of pits that steadily grew, i.e. lacelike pits (Figure 3(a)), on the surface of the F 138 steel specimens and, on the other hand, the absence of these pits on the surface of the ISO 5832-9 steel. This finding corroborates the already formulated assumptions based on the cyclic polarization behavior, and contributes to the statement that the presence of hysteresis in the cyclic polarization curve confirms the occurrence of pitting corrosion, while the absence of hysteresis excludes the possibility of this type of corrosion. Lacelike pits are responsible for the development of hysteresis in the cyclic polarization curve of the F 138 steel. The dimension of these pits favors the establishment of occluded cells and, consequently, the development of an extremely aggressive environment inside them.

The SEM examination of the F 138 steel specimens also revealed the following characteristics: (1) no evidences of corrosion associated with non-metallic inclusions was found; (2) a large number of small pits were observed in an incipient stage of growth, or even pits that had firstly initiated but repassivated, which could be responsible for the serrated portion in the passive region of the polarization curve (Figure 1); (3) the incipient pits remained approximately equi-axial, bordered by facets (Figure 3(b)). According to Newman and Franz (Newman and Franz, 1984), crystallographic facets are formed in the initial stage of growth, when the concentration of chloride ions inside the pit is still low compared to the concentration inside a pit in an advanced stage of growth. During growth, coalescence of existing pits with newly nucleated ones surrounding them may occur. When the conditions inside the pit become sufficiently aggressive, an active dissolution process is initiated, preferentially at the pit bottom, giving rise to deeper, irregular pits, as shown in Figure 3(a).

In the case of the ISO 5832-9 steel, corrosion pitting in an advanced stage of growth was not observed. However, a selective attack associated to the Z-phase precipitates $(\mathrm{CrNbN})$ abundant on the microstructure of this type of steel (Giordani et al., 2004) - has been observed, as shown in Figure 4. The selective attack removed most of the smaller particles, indicating that Z-phase, or even its surroundings, is less noble than the remaining austenitic matrix and actively dissolves at high potentials. If the Z-phase precipitation site dissolution is an anodic process, it may contribute to the increased current density in the high potential region (Figure 1). Since smaller Z-phase particles can be removed from the exposed surface, the shifting of the curve during reverse scan to lower current density values can also be attributed to the reduction of actively corrosive sites.

Only after the potentiodynamic polarization test, at potentials above $800 \mathrm{mV}$ SCE, was the degradation of coarse primary Z-phases by cracking (Figure 4(b)) observed, which was not investigated in this study. This degradation could be related to some mechanism of hydrogen embrittlement or even the formation of some compounds inside the Z-phase particle.

The addition of $\mathrm{Nb}$ and its fine precipitation at $\mathrm{Z}$-phase, during controlled thermomechanical processing, promotes grain refinement of the ISO 5832-9 steel (Giordani, Jorge Jr., Balancin, 2005). The association of fine grain structure with some amount of nitrogen in solid solution is responsible for the high strength of this austenitic stainless steel, even in the annealed condition. On the other hand, the coarse 


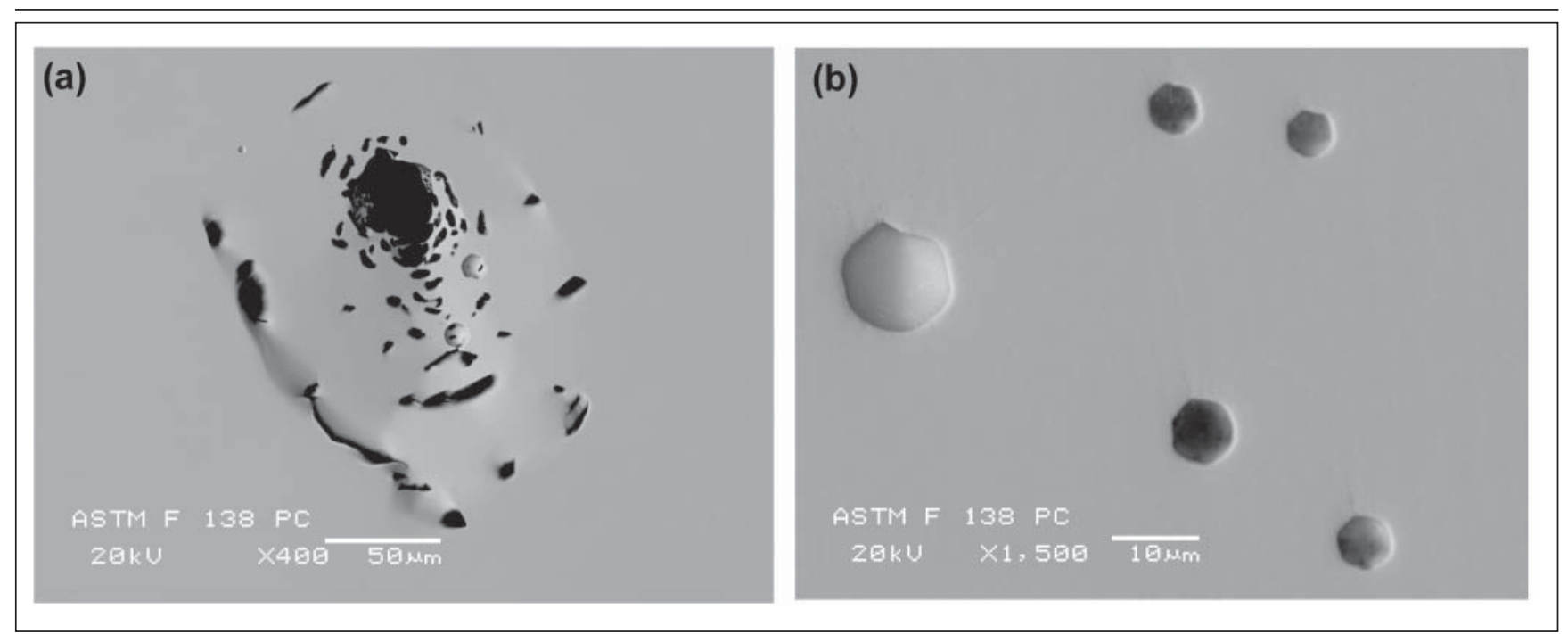

Figure 3 - SEM examination on the surface of the specimens of $F 138$ steel subjected to potentiodynamic cyclic polarization test: (a) lacelike pit in advanced stable growth; (b) crystallographic (faceted) pits in an incipient stage of growth or even pits that initiated but repassivated

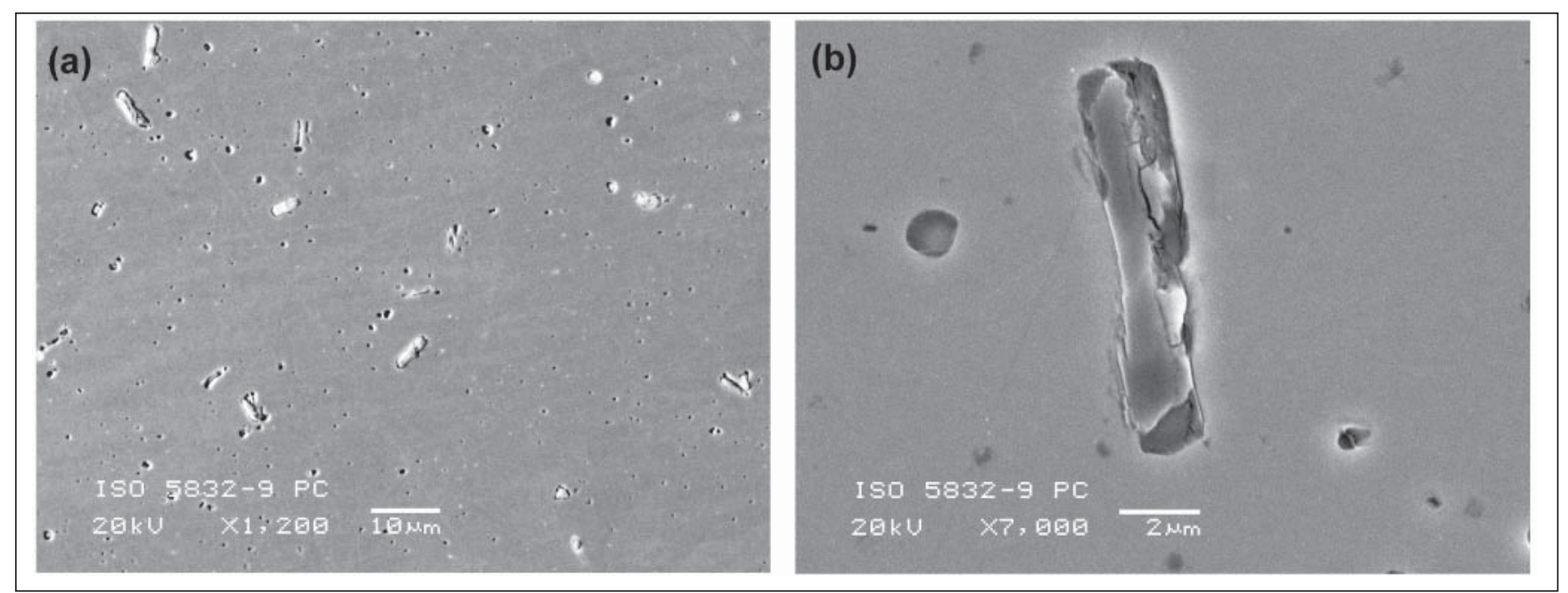

Figure 4 - SEM examination on the surface of specimens of ISO 5832-9 steel subjected to potentiodynamic cyclic polarization tests: selective attack of the Z-phase precipitates.

primary Z-phase precipitates, besides acting as fatigue crack initiation sites (Giordani et al., 2004), involve the removal of nitrogen, which is mainly responsible for the highly localized corrosion resistance of this steel, out of the solid solution. Based on this finding, one can suggest that the $\mathrm{Nb}$ addition should be carefully controlled so that coarse and excessive primary Z-phase precipitation is avoided.

\section{Conclusions}

Potentiodynamic and potentiostatic polarization tests in $0.9 \% \mathrm{NaCl}$ solution revealed that the ISO 5832-9 steel has a far higher pitting corrosion resistance than the F 138 steel. This property is attributed mainly to the increased passive film stability and high ability to repassivate, favored by the presence of nitrogen in interstitial solid solution in the austenite of this steel. SEM examination confirmed the presence of steadily growing corrosion pits (lacelike pits) on the surface of F 138 steel and the absence of such pits in the specimens of the ISO 5832-9 steel.
Potentiodynamic polarization test also show, at high potentials, that a selective attack associated to the Z-phase $(\mathrm{CrNbN})$ precipitation sites - abundant on the microstructure of the ISO 58329 steel - removed most of the smaller particles, indicating that these sites are less noble than the remaining austenitic matrix, and degraded the larger ones.

\section{Acknowledgements}

The authors are indebted to $\mathrm{CNPq}$ and FAPESP for their financial support of this work. 


\section{References}

AZUMA S., MIYUKI H., KUDO T. Effect of alloying nitrogen on crevice corrosion of austenitic stainless steels. ISIJ International, v. 36, n. 7, p. 793-798, 1996.

BANDY R., CAHOON J.R. Effect of composition on the electrochemical behaviour of austenitic stainless steel in Ringer's solution. Corrosion, v. 33, n. 6, p. 204-208, 1977.

CAHOON J.R., BANDYOPADHYA R., TENNESE $\mathrm{L}$. The concept of protection potential applied to the corrosion of metallic orthopedic implants. Journal of Biomedical Materials Research, v. 9, p. 259-264, 1975.

GIORDANI E.J., GUIMARÃES V.A., PINTO T.B., FERREIRA I. Effect of precipitates on the corrosion-fatigue crack initiation of ISO 5832-9 Stainless Steel Biomaterials. International Journal of Fatigue, v. 26, p. 11291136, 2004.

GIORDANI E.J., JORGE Jr. A.M., BALANCIN O. Evidence of straininduced precipitation on a $\mathrm{Nb}$ - and N-bearing austenitic stainless steel biomaterial. Materials Science Forum, v. 500-501, p. 179-186, 2005.

GIORDANI, E.J., FERREIRA I., BALANCIN, O. Propriedades mecânicas e de corrosão de dois aços inoxidáveis austeníticos utilizados na fabricação de implantes ortopédicos. REM - Revista da Escola de Minas, v. 60, n. 1, p. 5562, 2007.

GRABKE H.J. The role of nitrogen in the corrosion of iron and steels, ISIJ International, v. 36, n. 7, p. 777-786, 1996.

JARGELIUS-PETTERSSON R.F.A. Electrochemical investigation of the influence of nitrogen alloying on pitting corrosion of austenitic stainless steels. Corrosion Science, v. 41, p. 1639-1664, 1999.

JARGELIUS-PETTERSSON R.F.A. Sensitization behaviour and corrosion resistance of austenitic stainless alloyed with nitrogen and manganese. ISIJ International, v.36, n. 7, p. 818-824, 1996.

KAMACHI MUDALI U., DAYAL R.K., GNANAMOORTHY J.B., RODRIGUEZ P. Relationship between pitting and intergranular corrosion of nitrogen-bearing austenitic stainless steels. ISIJ International, v. 36, n. 7, p. 799-806, 1996.

LEVEY P.R., VAN BENNEKOM A. A Mechanistic study of the effects of nitrogen on the corrosion properties on stainless steels. Corrosion, v. 51, n. 12, p. 911-921, 1995

LIM Y.S., KIM J.S., AHN S.J., KWON H.S., KATADA Y. The influence of microestruture and nitrogen alloying on pitting corrosion of type $316 \mathrm{~L}$ and 20 wt.\% Mn-substituted type 316 L stainless steel. Corrosion Science, v.43, p.53-68, 2001.

LU Y.C., IVES M.B., CLAYTON C.R. Synergism of alloying elements and pitting corrosion resistance of stainless steels. Corrosion Science, v. 35, n.1-4, p. 89-96, 1993.

NEWMAN R.C., FRANZ E.M. Growth and repassivation of single corrosion pits in stainless steel. Corrosion, v. 40, p. $325-$ 330, 1984.

PAN J., KARLÉN C., ULFVIN C. Electrochemical study of resistance to localized corrosion of stainless steel for biomaterial applications. Journal of the Electrochemical Society, v. 147, p. 1021-1025, 2000
PESSALL N., LIU C. Determination of critical pitting potentials of stainless steels in aqueous chloride environments. Electrochimica Acta, v. 16, p. 987-1003, 1971.

PICKERING F.B. Lille, France, 1988. Some beneficial effect of nitrogen in steels. In: INTERNATIONAL CONFERENCE ON NITROGEN STEELS, Proceedings ed. by Foct, J. \& Hendry, A. The Institute of Metals, London, 1989, p.10-31.

RONDELLI G., VICENTINI B., CIGADA A. Influence of nitrogen and manganese on localized corrosion behaviour of stainless steels in chloride environments. Materials and Corrosion, v. 46, n.46, p. 628-632, 1995.

RONDELLI, G., VICENTINI, B., CIGADA, A. Localized corrosion tests on austenitic stainless steels for biomedical applications. British Corrosion Journal, v. 32, n. 3, 193-196, 1997.

SIVAKUMAR M., KAMACHI MUDALIU., RAJESWARI S. In vitro electrochemical investigations of advanced stainless steels for applications as orthopaedic implants. Journal of Materials Engineering and Performance, v. 3, n. 6, p. 744-753, 1994.

TRUMAN J.E., COLEMAN M.J., PIRT K.R. Note on the influence of nitrogen content on the resistance to pitting corrosion of stainless steels. British Corrosion Journal, v. 12, n. 4, p. 236238, 1977.

WILDE B.E., WILLIAMS E. Use of current/ voltage curve for study of localized corrosion and passivity breakdown on stainless steels in chloride media. Electrochimica Acta, v. 16, p. 1971-\&, 1971.

Artigo recebido em 03/06/2009 e aprovado em 18/01/2010.

\section{A REM tem novo endereço: FUNDAÇÃO GORCEIX - REM Rua Carlos Walter Marinho Campos, 57 Bairro: Vila Itacolomy 35400-000 - Ouro Preto - MG $\begin{array}{ll}\text { (31) } 3551-4730 & \text { (31) 3559-7408 }\end{array}$ www.rem.com.br}

